PSYCHOLOGIA ROZWOJOWA, $2017 *$ tom 22 , nr 2, s. 71-85

doi:10.4467/20843879PR.17.011.7043

www.ejournals.eu/Psychologia-Rozwojowa

\author{
ANNA SZYMANIK-KOSTRZEWSKA \\ Instytut Psychologii \\ Uniwersytet Kazimierza Wielkiego, Bydgoszcz \\ Institute of Psychology \\ Kazimierz Wielki University, Bydgoszcz \\ alex.shilou@gmail.com
}

JANUSZ TREMPAŁA

Instytut Psychologii

Uniwersytet Kazimierza Wielkiego, Bydgoszcz

Institute of Psychology

Kazimierz Wielki University, Bydgoszcz

\title{
Idealne rodzicielstwo: deklarowane przekonania i zachowanie matek małych dzieci
}

\author{
Perfect Parenting: Declared Beliefs and Behaviours \\ of Young Children's Mothers
}

\begin{abstract}
The purpose of this study was to define mothers' level of acceptance of beliefs and behaviours towards a child which are linked to three parental myths chosen by the authors: the myth of the supreme value of the child, of the need to ensure the child's happiness, and of making friends with the child. Furthermore, the authors wanted to discover if parental myth acceptance is linked to rating the reasons behind the parents' behaviour in accordance with these myths. In the study, 113 mothers (aged from 22 to 50) with at least one child of age between 1 and 7 participated. An Obsessive Mother to Child Love Questionnaire (OMCLQ) and a Modern Parent Stereotype Questionnaire (MPSQ) were used. The results of the study show that the parental myths selected by the authors are moderately accepted by the surveyed mothers, both when it comes to their beliefs and to behaviours towards the child.
\end{abstract}

Keywords: perfect parenting, parental myths, supreme value of child.

Słowa kluczowe: idealne rodzicielstwo, mity wychowawcze, nadrzędna wartość dziecka.

\section{WPROWADZENIE}

W różnych kręgach kulturowych obserwujemy różne podejścia do wychowania dzieci. Jednakże można zauważyć, że w krajach rozwiniętych i rozwijających się mimo dużego zróżnicowania podejścia te charakteryzuje wspólna cecha - przypisywanie dziecku szczególnie wysokiej wartości. Na przykład matki amerykańskie pro- mują ,zaangażowane macierzyństwo”, stawiając potrzeby dziecka na pierwszym miejscu w hierarchii wartości (Hays, 1996). Można mówić o zachowaniach charakterystycznych dla tak zwanych helikopterowych rodziców (helicopter parents) - bardzo zaangażowanych w życie swoich dzieci, silnie kontrolujących, ale jednocześnie udzielających ogromnego wsparcia (m.in. Padilla-Walker, Nelson, 2012; Schiffrin 
i in., 2014). Z kolei chińskie matki pokolenia jedynaków dążą do nieustannej stymulacji swoich dzieci, przyspieszania ich rozwoju i doskonalenia umiejętności, uznając je coraz częściej za najważniejszych członków rodziny (Chiu, 2007; Goh, 2011). Określane są mianem „małych słońc” czy też „małych imperatorów”. Dzieci te są otaczane przez rodziców szczególną troska, wysoko wartościowane - lecz szybko uczą się one wykorzystywać swoją nadrzędną pozycję w rodzinie (m.in. Goh, 2011; Miller, 2014). Przejawy wzrastającej wartości psychologicznej dziecka można zaobserwować także wśród polskich rodziców. Pojawiają się doniesienia o matkach poświęcających całe swoje życie dla dzieci o szczególnych potrzebach (Palęcka, Szczodry, 2010), ale także o ,perfekcyjnych matkach", godzących wszystkie swoje obowiązki (rodzinne, zawodowe, towarzyskie) z macierzyństwem, z którym doskonale sobie radzą (Bieńko, 2015). Wyniki badań dowodzą, że polepszanie się warunków socjoekonomicznych rodzin generalnie jest związane ze spadkiem dzietności i jednoczesnym wzrostem wartości emocjonalno-psychologicznej dziecka (Kagitcibasi, 1982; Kagitcibasi, Ataca, 2005), rozumianej jako czerpanie przez rodzica radości i szczęścia z kontaktu z dzieckiem (Nauck, 2014), którego istnienie wiąże się dla rodzica z poczuciem sensu życia (Umberson, Gove, 1989).

Powyższe zmiany w stosunku rodziców do dzieci nie są zgodne ze stereotypami pedagogiki przymusu (versus pedagogiki swobody, zob. Nawroczyński, 1929), które dominowały w myśleniu rodziców w pierwszej połowie XX wieku, a w pewnych kręgach kulturowych jeszcze dzisiaj funkcjonuja, to jest „,co wolno wojewodzie, to nie tobie, smrodzie”, „dzieci i ryby głosu nie mają", ,,przez tyłek po rozum do głowy" itp. U ich podstaw leżały przekonania o małej wartości dziecka (porównywalnej z rybami), przewadze dorosłych (fizycznej oraz umysłowej) i koniecznej dyscyplinie w respektowaniu tego, co dobre ze społecznego punktu widzenia, które uzasadniały pomijanie potrzeb i praw dzieci. Opozycyjna wobec tego stanowiska pedagogika przyzwolenia w wychowaniu, bez stresu i porażek (zob. m.in. Gordon, 1991; von Schoenebeck, 2008) czy bliskości rodziców z dzieckiem (ang. Attachment parenting, Bowlby, 1951, zob. Sears, Sears, 2001), zrodziła w drugiej połowie XX wieku nową ideologie stosunku do dziecka, zgodnie z która jest ono najważniejsze na świecie, należy je ochraniać i kochać, stale nagradzać, rozmawiać i zaprzyjaźnić się z nim, aby zagwarantować mu szczęście. Narrację tę uzasadnia przekonanie, z którym trudno dyskutować - że pełne poświęcenia zaangażowanie rodzicielskie (zob. Bakiera, 2013) zapewnia pomyślny rozwój i życie dziecka.

Analizując zmiany dające się zauważyć w stosunku do dziecka we współczesnych społeczeństwach krajów rozwijających się, Janusz Trempała (2010) doszedł do wniosku, że wzrost wartości dzieci zrodził nowe mity wychowawcze, rozumiane jako fałszywe opowieści i przekonania (zob. Tokarski, 1980) upowszechniane w przekazach społecznych bez dowodu, które nie zawsze oparte są na racjonalnych podstawach i nie znajduja jednoznacznego potwierdzenia w wynikach badań naukowych. Wyróżnił i opisał sześć mitów na temat idealnego rodzicielstwa, wskazując na wątpliwości związane z zawartymi w nich zasadami, którymi powinni kierować się rodzice w wychowaniu dzieci. W prezentowanych w opracowaniu badaniach uwage koncentrujemy na trzech wybranych, głoszących, że:

- dziecko jest najważniejsze na świecie;

- dziecku trzeba zapewnić szczęśliwe dzieciństwo;

- $\quad$ z dzieckiem trzeba się zaprzyjaźnić.

Pierwsze dwa mity wiążą się odpowiednio $\mathrm{z}$ inwestycją materialną i psychologiczna w rozwój dziecka - inwestycją, która powinna przynieść zyski w postaci wychowania bardzo zdolnego, a jednocześnie szczęśliwego dziecka. Mit pierwszy koresponduje bezpośrednio z obserwowanym współcześnie w Polsce wzrostem wartości emocjonalno-psychologicznej dziecka. W krajach rozwijających się poprawa warunków socjoekonomicznych zwykle wiąże się ze spadkiem dzietności (Kagitcibasi, 1982; Kagitcibasi, Ataca, 2005), a w połączeniu $z$ dostępem do antykoncepcji i możliwością planowania rodziny może prowadzić do traktowania rodzicielstwa jako ambitnego życiowego projektu (Cherlin, 
2000). Projekt ten przyjmuje formę inwestycji materialnej (Trempała, 2010), na którą składają się: obdarzanie dziecka drogimi zabawkami, zapewnianie mu jak najlepszej opieki medycznej, wykształcenia, pokarmów i produktów najwyższej jakości, a w konsekwencji ,zasypywanie” dziecka ogromną ilością przedmiotów, których nie jest ono w stanie wykorzystać. Wiara w pierwszy z mitów prowadzi nie tylko do nadmiernego inwestowania w dziecko zasobów materialnych, ale także poświęcania się na rzecz dziecka (zob. Senior, 2015), którego zachcianki uznawane są za ważniejsze od potrzeb rodzica.

Wiara $\mathrm{w}$ drugi z mitów powiązana jest $\mathrm{z}$ inwestycją psychologiczną rodzica w dziecko (Trempała, 2010). Forma treściowa mitu sprawia, iż rodzic pokładający w nim wiarę nabiera przekonania, iż jest wyłącznie odpowiedzialny za szczęście swojego dziecka. Odpowiedzialność ta staje się dla niego ogromnym obciążeniem, gdyż w sytuacji braku szczęścia dziecka rodzi poczucie winy. $Z$ drugiej strony rozumienie szczęścia przez rodzica nie musi pokrywać się z rozumieniem szczęścia przez dziecko. Niebezpieczeństwo stanowi także przekonanie rodzica, iż szczęście tożsame jest z brakiem smutku, stresu czy porażek w życiu dziecka. Stres jest potrzebny w życiu człowieka, jest jego nieodłącznym elementem, a jego doznawanie niejednokrotnie prowadzi do pozytywnych skutków - wzmacniając, motywując, dodając energii i pozwalając się rozwijać (m.in. Heszen, 2014; Selye, 1978). Rodzic, który „oszczędza” dziecku stresu i nadmiernie chroni je przed porażkami, uniemożliwia mu naukę ważnej umiejętności radzenia sobie $z$ frustracją, trudnościami i przeszkodami, co z kolei rzutuje na dalsze życie dziecka. J. Trempała (2010) sugeruje również, iż nadopiekuńczość rodziców, wynikająca z przekonania, iż muszą zapewnić dziecku szczęście, może przyczyniać się do niechęci dziecka do opuszczenia domu w dorosłości i wydłużania okresu moratorium - wkraczania w dorosłość (zob. Arnett, 2004; Liberska, 2007).

Trzeci z mitów prowadzi do mylenia przyjaźni z przyjaznym traktowaniem dziecka przez rodzica (Trempała, 2010). Rodzic sprawuje rolę opiekuna, chroniąc dziecko i wspierając je. Rola ta wynika z potrzeb rozwojowych dziecka, które w pierwszych latach swojego życia potrzebuje ze strony dorosłego nie tylko opieki (Bakiera, 2013), a także szeroko pojętej kontroli (ustanawiania zasad i ich egzekwowania, stawiania granic itd.), która pozwoli dziecku rozwinąc samokontrolę (Kopp, 1982) czy dojrzałą moralność (Trempała, Czyżowska, 2004). Przyjaźń natomiast jest relacją równorzędną, opartą na wzajemnym dbaniu o siebie i udzielaniu sobie emocjonalnego wsparcia (zob. Sternberg, 1986). Rodzice, którzy wierzą w mit o konieczności zaprzyjaźnienia się z dzieckiem, mogą tym samym zaburzać relację rodzic-dziecko poprzez traktowanie dziecka jako równorzędnego partnera czy obarczanie nadmierną odpowiedzialnością, oczekując od niego opieki czy wsparcia (zob. Kościelska, 2011).

Model ,idealnego rodzicielstwa” oparty na trzech wspomnianych mitach i popularyzowany w licznych przekazach społecznych staje się wzorem do naśladowania dla wielu matek, które starają się perfekcyjnie wywiązywać z zadań wynikających z bycia rodzicem. Akceptacja mitów wychowawczych, wyrażająca się w przejmowanych przez rodziców przekonaniach i wzorach zachowania wobec dziecka, nie musi jednakże odbywać się bezrefleksyjnie.

Starając się opisać podłoże kulturowe nadmiernie zaangażowanego, ,idealnego" macierzyństwa, wyszliśmy z założenia, iż możemy mówić o pewnych stereotypowych przekonaniach na temat obserwowanego przez matki postępowania rodziców względem dzieci. Przyjęliśmy podręcznikową definicję stereotypu jako generalizacji odnoszącej się do grupy, której członkom przypisywane są identyczne charakterystyki (zob. Aronson, Wilson, Akert, 1997). Stereotypowe przekonania na temat wychowania rozumiemy jako uproszczone wyjaśnienia zachowań rodzicielskich, uogólniane na postępowanie wszystkich rodziców. Mogą mieć one postać generalizowanej na rodziców (wszyscy lub większość rodziców tak postępuje, to naturalne, normalne, często tak się dzieje) racjonalizacji (to zachowanie jest dobre, korzystne, nie tak złe jak zachowanie alternatywne) bądź przypisywanej im motywacji (dla dobra dziecka, w obawie przed czymś, żeby uniknąć czegoś złego). Uogólnienia te są 
najczęściej nieuprawnione, jednakże przekonanie, iż „wszyscy tak postępują”, niejednokrotnie stanowi usprawiedliwienie dla rodzica, który nie jest pewny, czy jego zachowanie rzeczywiście jest właściwe.

Opierając się na teorii wyrozumowanego działania (zob. Ajzen, Fishbein, 1980; Fishbein, Ajzen, 1975), można przyjąć, że we wnioskowaniu o planowanych i rozmyślnych zachowaniach rodziców w wychowaniu dzieci najlepszą podstawą mogą być ich postawy wyrażone w akceptacji/odrzuceniu przekonań na temat konkretnych zachowań wobec dziecka oraz ich subiektywne normy, tworzące się w oparciu o wpływ społeczny. Jeśli rodzic pochwala zachowania przypisywane innym rodzicom, znajdując dla nich racjonalne - jego zdaniem wyjaśnienia, najprawdopodobniej są one przez niego powielane.

Wyszliśmy z założenia, iż stereotypowe wyjaśnienia zachowań rodziców względem dzieci mogą stanowić jedną z przyczyn kierowania się rodziców mitami wychowawczymi w myśleniu oraz działaniu, swojego rodzaju ,racjonalny powód”, by wierzyć w zdolność bycia „,idealnym rodzicem". Zachowania, których relacji z mitami wychowawczymi doszukiwaliśmy się w prezentowanych badaniach, dotyczyły takich zagadnień jak:

1. Matki, uznając dziecko za najważniejsze na świecie, inwestują w jego edukację, aby zapewnić mu powodzenie (zob. Długosz, 2013).

2. Matki, uznając dziecko za najważniejsze na świecie, poświęcają się dla niego w obawie przed zarzutem zaniedbań (zob. Trempała, 2010).

3. Matki pragną szczęścia dla swojego dziecka, bo tego chce każdy dobry rodzic (zob. Senior, 2015).

4. Matki obdarowują dziecko rzeczami, których - ich zdaniem - ono pragnie, by je uszczęśliwić (zob. Trempała, 2010).

5. Matki przyjaźnią się z dzieckiem, by zapewnić ufne z nim relacje (zob. Sears, Sears, 2001).

6. Matki przyjaźnią się z dzieckiem, by dać mu ciepło emocjonalne (zob. Baumrind, 1972; Maccoby, Martin, 1983).
Celem prezentowanych badań było określenie stopnia akceptacji przez badane matki przekonań i zachowań wobec dziecka, związanych z trzema wybranymi przez nas mitami wychowawczymi, które są rozpowszechniane we współczesnym społeczeństwie: o nadrzędnej wartości dziecka; konieczności zapewnienia mu szczęścia; i zaprzyjaźnienia się z nim. Ponadto chcieliśmy dowiedzieć się, czy akceptacja przez badane matki przekonań odpowiadających tym mitom jest związana $\mathrm{z}$ ich sądami na temat powodów postępowania zgodnego $\mathrm{z}$ tymi mitami przez większość rodziców.

\section{METODA}

\section{Próba osób badanych}

Z prośbą o udział w badaniach zwrócono się do matek, które miały przynajmniej jedno dziecko w wieku 1-7 lat. Dobór do próby dokonano opierając się na metodzie „kuli śnieżnej”, w rekrutację badanych włączyli się również studenci psychologii (około 35\% matek stanowiły znajome studentów). W badaniach wzięło udział 113 matek w wieku od 22 do 50 lat $(\mathrm{M}=33,56$; $\mathrm{SD}=5,58)$, $\mathrm{z}$ czego $81 \%$ pozostawało $\mathrm{w}$ związkach formalnych ( $1 \%$ nie pozostawał w związku, $18 \%$ - w związkach nieformalnych), $83 \%$ deklarowało przeciętną sytuację materialną (4\% poniżej przeciętnej, $13 \%$ - powyżej) i $65 \%$ wykształcenie wyższe ( $8 \%$ - o zawodowym/ podstawowym, $27 \%$ - średnim). Średnia liczba dzieci badanych matek wynosiła $2(\mathrm{SD}=1.1)$, wiek dzieci, których dotyczyły odpowiedzi matek, mieścił się $\mathrm{w}$ granicach $1-7$ lat $(\mathrm{M}=4.5$; $\mathrm{SD}=1.8)$. W grupie tych dzieci znalazło się 60 dziewcząt i 53 chłopców.

Wszystkie uzyskane wyniki zostały włączone do analizy. Zgromadzone dane były kompletne w ponad $99 \%$, na etapie analizy statystycznej ubytki zastąpiono średnimi.

\section{Pomiar}

Badania stanowiły część szerszego projektu (zob. Szymanik-Kostrzewska, 2016), w który zaangażowani byli autorzy artykułu oraz Mi- 
chalina Zychal ${ }^{1}$. Projekt uzyskał pozytywną opinię Komisji do spraw Etyki Badań Naukowych, działającej przy Instytucie Psychologii UKW. Uczestnictwo w badaniach było anonimowe i dobrowolne, do momentu oddania pakietu kwestionariuszy możliwe było wycofanie zgody na badania (żadna z badanych matek nie skorzystała z tej możliwości).

Zastosowano następujące narzędzia badawcze:

1. Kwestionariusz Obsesyjnej Miłości Matki do Dziecka (KOMMD). W prezentowanych badaniach wykorzystano trzy skale odpowiadające wybranym mitom (szerzej na temat kwestionariusza zob. Szymanik-Kostrzewska, 2016). Każda ze skal składała się z dwóch podskal - przekonań (podskale „a”) oraz adekwatnych do nich, deklarowanych zachowań (podskale „b”). Zadaniem badanych było określenie (w oparciu o skalę Lickerta od 1 do 5) stopnia, w którym zgadzają się $\mathrm{z}$ danym stwierdzeniem (zdecydowanie się nie zgadzam; raczej się nie zgadzam; trudno powiedzieć, czy zgadzam się czy nie; raczej się zgadzam; zdecydowanie się zgadzam). Stwierdzenia prezentowano w kolejności losowej. Trafność teoretyczną KOMMD określiło trzech sędziów kompetentnych, psychologów, na podstawie zgodności stwierdzeń danych skal z przyjętymi opisami:

- Skala Wartość Dziecka (WD, 7 par i jedna trójka stwierdzeń): Dziecko jest najważniejsze na świecie i bezwzględnie powinno dostać od rodzica to, co najlepsze - ubrania, jedzenie, zabawki, zdobycze technologii, opiekę domową i lekarską, edukację. Zachowanie rodzica jest podporządkowane zasadzie maksymalnych inwestycji w potrzeby dziecka, nawet kosztem własnych potrzeb.

- Skala Szczęśliwe Dzieciństwo (SD, 8 par stwierdzeń): Rodzic jest odpowiedzialny za to, by dziecko miało szczęśliwe dzieciństwo i musi spełniać oczekiwania dziecka, które wiążą się z jego szczęściem. Uważa, że szczęście zapewni mu to, czego jemu brakowało w dzieciństwie. Jest przekonany, że dziecko powinno być chronione przed stresami i porażkami, nie wolno go obarczać nadmiernymi obowiązkami. Należy wyręczać je w trudnych lub nielubianych przez nie zadaniach.

- Skala Przyjaźń z dzieckiem (P, 6 par stwierdzeń): Rodzic powinien się z dzieckiem zaprzyjaźnić, traktować je jako równoprawnego partnera. Zakłada się równość stosunków pomiędzy rodzicem i dzieckiem.

Po dokonaniu korekty stwierdzeń zalecanej przez sędziów udało się osiagnąc ich pełną zgodność. Rzetelność pomiaru dla poszczególnych podskal KOMMD oszacowana została na podstawie współczynników $\alpha$ Cronbacha, które w poszczególnych skalach wahały się od 0,72 do 0,78 .

2. Kwestionariusz Stereotypu Współczesnego Rodzica (KSWR) ${ }^{2}$. Narzędzie stworzono $\mathrm{w}$ oparciu o strategię indukcyjną na podstawie głównych założeń poszczególnych skal KOMMD. Do badań wykorzystano wersję pilotażowa. Na każdą ze skal KOMMD przypadały po dwa stereotypowe wyjaśnienia zachowań rodziców powiązanych treściowo z odpowiednimi mitami wychowawczymi. Stereotypowe wyjaśnienia zachowań odpowiadających skali Wartość Dziecka (SWR-WD) odnosiły się do zapewnienia dziecku wysokiej jakości wykształcenia, podyktowanego troską o przyszłość (SWR-WD1), oraz umniejszania swoich potrzeb przez rodzica na rzecz stymulowania rozwoju dziecka (SWR-WD2).

Zachowania odnoszące się do skali Szczęśliwe Dzieciństwo (SWR-SD) dotyczyły chęci zapewnienia przez rodzica szczęścia dziecku, rozumianego jako ,naturalne" zachowanie rodzica (SWR-SD1) oraz podyktowane lękiem by dziecku nie zabrakło tego, czego rodzicowi brakowało w dzieciństwie (SWR-SD2).

Zachowania charakterystyczne dla skali „Przyjaźń z dzieckiem” (SWR-P) dotyczyły przyjaźni rodzica jako warunku ufności dziecka (SWR-P1) oraz jej braku kojarzonego z niezdolnością rodzica do czułości (SWR-P2).

\section{Model testowanych relacji}

Zgodnie z celem badań oraz zarysowanymi we Wprowadzeniu założeniami teoretycznymi, przyjęliśmy model badawczy zaprezentowany na rysunku 1. 
Założyliśmy, iż:

1. Akceptacja przekonań na temat wychowania będzie współwystępować z deklaracjami postępowania adekwatnego do przekonań.

2. Akceptacja stereotypowych wyjaśnień postępowania rodziców będzie współwystępować $\mathrm{z}$ akceptacją adekwatnych przekonań na temat wychowania.

3. Akceptacja stereotypowych wyjaśnień postępowania rodziców będzie współwystępować z deklaracjami na temat adekwatnych zachowań rodzicielskich.
Ponieważ odpowiedzi udzielano na skali (Lickerta) o przedziale od 1 do 5, przyjęto, iż wyniki mieszczące się w obrębie \pm jednego odchylenia standardowego od 3 (przy spełnionym założeniu o rozkładzie zbieżnym z normalnym) są średnie, powyżej - wysokie, poniżej - niskie. Wyniki dla wszystkich podskal mieściły się w przedziale średnich, z wyjątkiem podskali Wartość Dziecka - zachowania (WDb), dla której wynik ogólny był wysoki.

Na podstawie różnic w średnich dla poszczególnych skal (użyto testu t dla zmiennych zależnych do wstępnego określenia różnic, wielkość

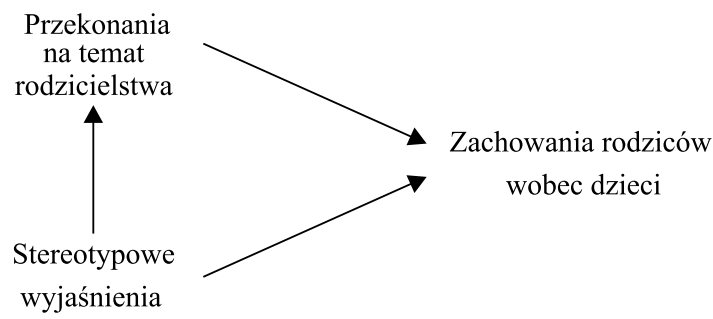

Rysunek 1. Hipotetyczny model badanych relacji między zmiennymi

\section{WYNIKI BADAŃ}

\section{Przekonania i zachowania matek wobec dziecka}

W pierwszej kolejności określono akceptację matek wobec przekonań opartych na mitach wychowawczych oraz odpowiadających poszczególnym mitom, deklarowanych przez matki zachowań. Średnie i odchylenia standardowe dla poszczególnych skal i podskal KOMMD zaprezentowano w tabeli 1. efektu oszacowano na podstawie $d$ Cohena) można przyjąć, iż:

- dla podskal przekonań najwyższym wynikiem charakteryzowała się Pa (Przyjaźń z Dzieckiem), niższym - WDa (Wartość Dziecka) $(t=3.32 ; p=.001 ; d=.34)$, najniższym natomiast - SDa (Szczęśliwe Dzieciństwo) $(t=-6.41 ; p<.001 ; d=.48)$;

- dla podskal zachowań zaobserwowano wyższe wyniki w przypadku WDb i Pb (Wartość Dziecka i Przyjaźń z Dzieckiem), niższy w przypadku SDb (Szczęśliwe Dzieciństwo)

Tabela 1. Średnie i odchylenia standardowe dla podskal Kwestionariusza Obsesyjnej Miłości Matki do Dziecka (KOMMD)

\begin{tabular}{|l|c|c|c|c|}
\hline \multirow{2}{*}{ Skale } & \multicolumn{2}{|c|}{ Podskala „a”- przekonanie } & \multicolumn{2}{c|}{ Podskala „,b”- postępowanie } \\
\cline { 2 - 5 } & $\mathbf{M}$ & SD & M & SD \\
\hline WD - Wartość Dziecka & 3.29 & .64 & 3.69 & .63 \\
\hline SD - Szczéśliwe Dzieciństwo & 2.98 & .65 & 3.14 & .69 \\
\hline P - Przyjaźń z Dzieckiem & 3.52 & .72 & 3.64 & .65 \\
\hline d Cohena & Pa > WDa > SDa & \multicolumn{2}{l|}{ WDb > SDb; Pb > SDb } \\
\hline
\end{tabular}


(odpowiednio: $t=-10.5 ; p<.001 ; d=.83$ oraz $t=-7.61 ; p<.001 ; d=.75)$.

Dodatkowo przeprowadzono szczegółową analizę odpowiedzi dla poszczególnych stwierdzeń. Stwierdzeniem, z którym badane matki zgadzały się w największym stopniu, była pozycja z podskali WDa: „Dobry rodzic powinien zapewnić dziecku jak najwięcej różnych zabawek, książek czy filmów" $(\mathrm{M}=4.65 ; \mathrm{SD}=.73$; $t=2.22 ; p=.03$ względem następnego stwierdzenia w kolejności).

Z kolei w najmniejszym stopniu badane matki zgadzały się ze stwierdzeniami z podskali SDa: „Dobry rodzic nie powinien odmawiać dziecku tego, czego ono bardzo chce" $(\mathrm{M}=1.98$; $\mathrm{SD}=.94 ; t=-3.72 ; p<.001$ względem następnego stwierdzenia w kolejności) i „Rodzic nie powinien zmuszać dziecka do robienia czegoś, czego ono nie lubi, tylko je w tym zastąpić" $(\mathrm{M}=2 ; \mathrm{SD}=1.07 ; t=-3.67 ; p<.001$ względem poprzedniego stwierdzenia w kolejności).

\section{Stereotypowe wyjaśnienia}

Analizę wyników dla stereotypowych wyjaśnień rozpoczęto od określenia akceptacji matek dla poszczególnych wyjaśnień. Średnie i odchylenia standardowe dla wyników poszczególnych stwierdzeń KSWR zaprezentowano w tabeli 2.

Wyniki dla wszystkich stwierdzeń poza SWR-SD1 oraz SWR-P2 mieściły się w przedziale wysokich, co oznacza znaczącą akceptację większości stereotypowych wyjaśnień przez badane matki.

\section{Związek między przekonaniami i zachowaniami oraz ich wyjaśnieniami}

W pierwszym kroku analizy określono relacje przekonań badanych matek i deklarowanych przez nie zachowań, co przedstawia tabela 3.

Pomiędzy przekonaniami matek a deklaracjami zachowań zaobserwowano dodatnie,

Tabela 2. Średnie i odchylenia standardowe dla pozycji Kwestionariusza Stereotypu Współczesnego Rodzica (KSWR)

\begin{tabular}{|c|c|c|c|}
\hline Skale KSWR & Pozycje KSWR & $\mathbf{M}$ & SD \\
\hline \multirow{2}{*}{$\begin{array}{l}\text { SWR-WD - Stereotyp Współ- } \\
\text { czesnego Rodzica - Wartość } \\
\text { Dziecka }\end{array}$} & $\begin{array}{l}\text { SWR-WD1. Zapewnianie wykształcenia w obawie } \\
\text { przed brakiem pracy dla dziecka }\end{array}$ & 4.21 & .86 \\
\hline & $\begin{array}{l}\text { SWR-WD 2. Poświęcanie się dla dziecka w obawie } \\
\text { przed zaniedbaniem }\end{array}$ & 3.92 & .91 \\
\hline \multirow{2}{*}{$\begin{array}{l}\text { SWR-SD - Stereotyp Współ- } \\
\text { czesnego Rodzica - Szczęśli- } \\
\text { we Dzieciństwo }\end{array}$} & $\begin{array}{l}\text { SWR-SD1. Zapewnienie szczęścia jako rzecz natu- } \\
\text { ralna, alternatywę wyjaśnia egoizm rodzica }\end{array}$ & 3.88 & .93 \\
\hline & $\begin{array}{l}\text { SWR-SD 2. Dawanie dziecku tego, czego rodzic nie } \\
\text { miał, w obawie przed odczuwanym przez dziecko } \\
\text { brakiem }\end{array}$ & 3.97 & .9 \\
\hline $\begin{array}{l}\text { SWR-P - Stereotyp Współ- } \\
\text { czesnego Rodzica - Przyjaźń } \\
\text { z Dzieckiem }\end{array}$ & $\begin{array}{l}\text { SWR-P1. Przyjaźń z dzieckiem implikująca jego } \\
\text { zaufanie wobec rodzica i świadomość możliwości } \\
\text { proszenia o pomoc }\end{array}$ & 4.12 & .79 \\
\hline
\end{tabular}

Tabela 3. Korelacje pomiędzy podskalami „a” oraz „b” Kwestionariusza Obsesyjnej Miłości Matki do Dziecka (KOMMD)

\begin{tabular}{|l|l|l|c|}
\hline \multicolumn{1}{|c|}{ Podskale „a” oraz ,b” } & $\boldsymbol{r}$ & $\boldsymbol{R}^{\mathbf{2}}$ & $\boldsymbol{p}$ \\
\hline WD - Wartość Dziecka & .72 & .52 & $<.001$ \\
\hline SD - Szczę́liwe Dzieciństwo & .67 & 45 & $<.001$ \\
\hline P - Przyjaźń z Dzieckiem & .78 & .61 & $<.001$ \\
\hline
\end{tabular}


istotne statystycznie korelacje $r$-Pearsona. Procent zmienności zachowań wyjaśniany przez zmienność przekonań badanych matek był we wszystkich przypadkach umiarkowany.

Dodatkowo przeanalizowano znaczenie kontrolowanych zmiennych ubocznych. Ani liczba, ani płeć dzieci nie różnicowały wyników podskal KOMMD, wiek matek również nie miał znaczenia. Natomiast zaobserwowano istotną korelację dodatnią pomiędzy wiekiem dzieci a wynikami podskal $\mathrm{Pa} \mathrm{i} \mathrm{Pb}$ - matki starszych dzieci deklarowały większą akceptację przekonań $(r=.25 ; p=.008)$ oraz zachowań $(r=.24 ; p=.01)$ ukierunkowanych na przyjaźń z dzieckiem niż matki dzieci młodszych.
- przekonania o konieczności zaprzyjaźnienia się rodzica z dzieckiem $(\mathrm{Pa})$ i wyjaśnienie poprzez powiązanie przyjaźni z zaufaniem dziecka wobec rodzica (SWR-P1): $r=.44$; $p<.001$;

- zachowania ukierunkowane na zaprzyjaźnienie się rodzica $\mathrm{z}$ dzieckiem $(\mathrm{Pb})$ i wyjaśnienie poprzez powiązanie przyjaźni z zaufaniem dziecka wobec rodzica (SWR-P1): $r=.44 ; p<.001$.

$\mathrm{Na}$ ostatnim etapie analizy włączono do modelu zarówno przekonania i zachowania matek, jak i akceptację stereotypowych wyjaśnień. Zastosowano analizę regresji wielorakiej, która w kolejnych trzech krokach wskazała zależności przedstawione na rysunkach 2,3 i 4 .

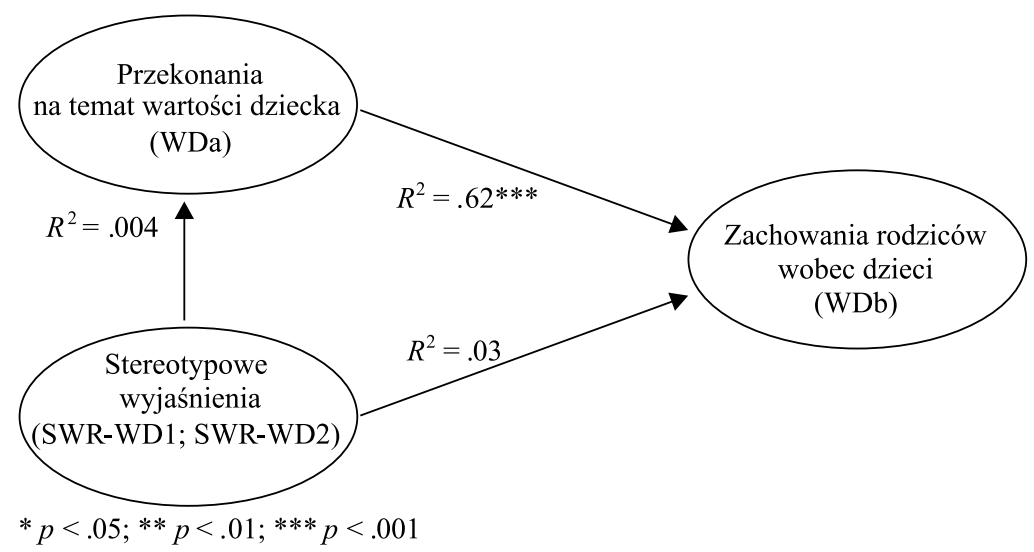

Rysunek 2. Wyniki analizy regresji w podskalach Wartość Dziecka (WD). Obraz testowanych relacji pomiędzy przekonaniami (WDa) i zachowaniami rodziców wobec dzieci (WDb) oraz stereotypowymi wyjaśnieniami (SWR-WD)

W następnym kroku analizy określono relację pomiędzy przekonaniami i zachowaniami matek a ich akceptacją stereotypowych wyjaśnień. Istotne statystycznie, dodatnie korelacje $r$-Spearmana (zastosowane ze względu na brak rozkładów normalnych dla zmiennych KSWR) zaobserwowano pomiędzy następującymi podskalami KOMMD i stwierdzeniami KSWR:

- zachowania ukierunkowane na zapewnienie dziecku szczęśliwego dzieciństwa (SDb) i ich wyjaśnienie poprzez chęć dania dziecku tego, czego rodzicowi brakowało (SWR-SD2): $r=.42 ; p<.01$;
W podskalach Wartość Dziecka (WD) zachowania badanych (WDb) dają się wyjaśnić w sposób istotny jedynie ich przekonaniami (WDa: $R^{2}=.62 ; F=13.84 ; p<.001$ ). Żadne z dwóch stereotypowych wyjaśnień - inwestowanie w edukację dziecka w obawie przed brakiem pracy (SWR-WD1) i poświęcanie się w obawie przed zaniedbaniem (SWR-WD2) nie miało istotnego znaczenia ani dla przekonań, ani dla zachowań matek.

W podskalach Szczęśliwego Dzieciństwa (SD) zachowania badanych (SDb) wyjaśniane były zarówno akceptacją przekonań (SDa: $\left.R^{2}=.53 ; F=9.8 ; p<.001\right)$, jak i stereotypowymi 
wyjaśnieniami zachowań rodziców (SWR-WD: $\left.R^{2}=.17 ; F=7.52 ; p<.01\right)$. Bardziej szczegółowa analiza relacji między zmiennymi pokazała, że istotnym predyktorem deklarowanych przez matki zachowań zapewniających dziecku szczęście było jedynie wyjaśnienie, że rodzice zwykle obdarowują swoje dzieci rzeczami, których im brakowało w dzieciństwie (SWR-SD2: $F=12.4 ; p<.001)$. Akceptacja stwierdzenia, że rodzice zwykle uważają zapewnienie dziecku szczęścia za „naturalne” zachowanie dobrych rodziców, okazała się być nieistotna jako wyjaśnienie deklarowanych przez matki zachowań wobec własnego dziecka (SWR-SD1: $F=.25$; $p=.62$ ). Żadne $\mathrm{z}$ uwzględnionych w badaniu stereotypowych wyjaśnień nie miało istotnego znaczenia dla przekonań.

W podskalach Przyjaźni z Dzieckiem (P) istotną $\mathrm{W}$ wyjaśnianiu zachowań badanych matek $(\mathrm{Pb})$ okazała się zarówno akceptacja przez matki przekonań $\left(\mathrm{Pa}: R^{2}=.65 ; F=21,55\right.$; $p<.001)$, jak i stereotypowych wyjaśnień (SWR-P: $R^{2}=.22 ; F=10.65 ; p<.01$ ). Szczegółowa analiza oddziaływania między zmiennymi ujawniła, że istotnym predyktorem deklarowanych zachowań matek, ukierunkowanych na

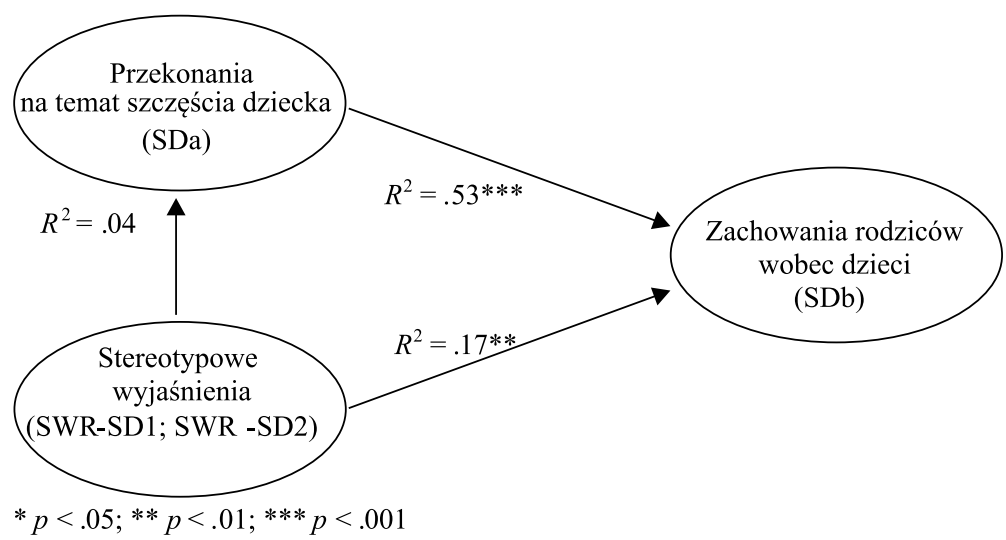

Rysunek 3. Wyniki analizy regresji w podskalach Szczęśliwe Dzieciństwo (SD). Obraz testowanych relacji pomiędzy przekonaniami (SDa) i zachowaniami rodziców wobec dzieci (SDb) oraz stereotypowymi wyjaśnieniami (SWR-SD)

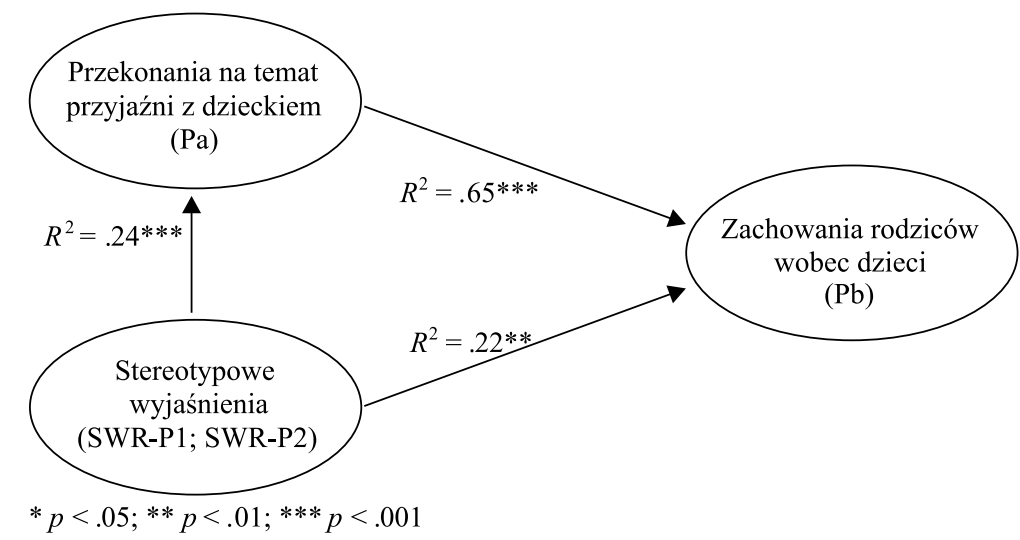

Rysunek 4. Wyniki analizy regresji w podskalach Przyjaźń z Dzieckiem (P). Obraz testowanych relacji pomiędzy przekonaniami $(\mathrm{Pa})$ i zachowaniami rodziców wobec dzieci $(\mathrm{Pb})$ oraz stereotypowymi wyjaśnieniami (SWR-P) 
przyjaźń z dzieckiem, jest jedynie utożsamianie przyjaźni z zaufaniem dziecka wobec rodzica (SWR-P1: $F=5.98 ; p<.001$; SWR-P2: $F=.31$; $p=.58)$. Ponadto, stereotypowe wyjaśnienia okazały się również istotnym predyktorem przekonań matek o konieczności zapewnienia dziecku szczęścia $\left(R^{2}=.24 ; F=11.89 ; p<.001\right)$.

Ponieważ wystąpiły istotne rozbieżności pomiędzy deklarowanymi przez matki przekonaniami i zachowaniami na temat wartości dziecka i zaprzyjaźnienia się z nim, przeprowadziliśmy analizę korelacji, która wykazała spójność deklarowanych przez badane matki przekonań i zachowań wobec dzieci. Okazało się, że przekonania wyjaśniały zachowania deklarowane przez matki w sposób istotny w zakresie od 45 do $61 \%$ zmienności.

\section{PODSUMOWANIE}

Pierwsze z postawionych przez nas pytań dotyczyło stopnia akceptacji przez badane matki przekonań na temat „nadrzędnej wartości dziecka”, „konieczności zapewnienia mu szczęścia” oraz „zaprzyjaźnienia się z dzieckiem”. Wyniki analizy doprowadziły do dwóch zasadniczych wniosków: badane matki w umiarkowanym stopniu zgadzały się ze stwierdzeniami składającymi się na powyższe przekonania oraz najbardziej akceptowały przekonanie o konieczności zaprzyjaźnienia się rodzica z dzieckiem, następnie o nadrzędnej wartości dziecka, a w najmniejszym stopniu - zapewnienie mu szczęścia.

Drugie ze sformułowanych przez nas pytań dotyczyło stopnia akceptacji przez badane matki zachowań odpowiadających przekonaniom o ,nadrzędnej wartości dziecka”, „konieczności zapewnienia mu szczęścia” oraz „zaprzyjaźnienia się z dzieckiem". Analiza doprowadziła do dwóch wniosków: uczestniczki badania deklarowały umiarkowane natężenie zachowań ukierunkowanych na zapewnienie dziecku szczęśliwego dzieciństwa oraz zaprzyjaźnienia się z nim, wysokie natomiast - zachowań powiązanych z przypisywaniem dziecku nadrzędnej wartości oraz - podobnie jak w przypadku przekonań zachowania ukierunkowane na zapewnienie dziecku szczęśliwego dzieciństwa były w tym porównaniu najrzadziej deklarowane przez badane matki. Nie wystapiły jednak, obserwowane $\mathrm{w}$ analizie przekonań, istotne różnice pomiędzy deklarowanymi przez matki zachowaniami ukierunkowanymi na podnoszenie wartości dziecka i zaprzyjaźnienia się z nim.

Jeśli chodzi o umiarkowaną spójność przekonań i zachowań badanych matek, uzyskany wynik nie wydaje się zaskakujący w świetle badań pokazujących, że wraz ze wzrostem podobieństwa treściowego i poziomu konkretności mierzonych postaw i zachowań społecznych (o co staraliśmy się w konstrukcji zastosowanych narzędzi) wzrasta korelacja między nimi (zob. np. Davidson, Jaccard, 1979; Ajzen, Fishbein, 1980). Niewykluczone, że przy zwiększeniu poziomu konkretności i zgodności treściowej badanych przez nas przekonań i zachowań korelacje te byłyby jeszcze wyższe. Stwierdzenie to sugeruje kierunek dalszego doskonalenia zastosowanych przez nas narzędzi pomiaru.

Powyższe wnioski, dotyczące akceptacji przez matki przekonań oraz zachowań wobec dziecka, generalnie potwierdzają przyjęte przez nas założenie o znacznej ich popularności wśród polskich rodziców. Są one zgodne z tendencjami do dążenia, by być idealnym rodzicem, obserwowanymi w kulturze chińskiej i amerykańskiej (zob. Chiu, 2007; Goh, 2011; Hays, 1996).

Dodać należy, że spośród kontrolowanych zmiennych ubocznych (tj. wiek matek, sytuacja materialna, stan cywilny, wykształcenie, miejsce zamieszkania, płeć i wiek dziecka) czynnikiem istotnie modulującym pomiar badanych zmiennych okazał się jedynie wiek dziecka, i to tylko w jednym zakresie - matki starszych dzieci w większym stopniu akceptowały przekonania i zachowania ukierunkowane na zaprzyjaźnienie się $\mathrm{z}$ dzieckiem. Wynik ten może świadczyć o tym, że badane matki są świadome ograniczeń w przyjaźnieniu się z młodszymi dziećmi ze względu na brak wzajemności w relacjach $\mathrm{z}$ nimi.

Celem prezentowanych badań było również określenie, czy deklarowane przez badane matki przekonania o „nadrzędnej wartości dziecka”, „konieczności zapewnienia mu szczęścia” i „,zaprzyjaźnienia się nim” oraz odpowiadające im 
zachowania wobec dziecka, są związane z sądami badanych na temat powodów wyjaśniających postępowanie w tym zakresie innych rodziców wobec swoich dzieci. Wyniki zastosowanej analizy potwierdziły założony w przyjętym modelu teoretycznym (zob. rysunek 1) kierunek relacji między badanymi przekonaniami i zachowaniami matek wobec dzieci: przekonania matek na temat wartości dziecka, jego szczęścia i konieczności zaprzyjaźnienia z nim wyjaśniają w sposób istotny deklarowane przez nie zachowania rodzicielskie. Jednak, pomimo że stopień akceptacji zdecydowanej większości wyróżnionych przez nas stereotypowych wyjaśnień był wysoki, wyjaśniały one przekonania i zachowania badanych matek wobec ich dzieci w ograniczonym zakresie.

Relatywnie niewielkie znaczenie stereotypowych wyjaśnień postępowania rodziców w przewidywaniu przekonań i zachowania badanych matek wobec własnych dzieci nasuwa kilka wniosków. Przede wszystkim sformułowane przez nas stereotypowe wyjaśnienia mogły nie pokrywać się z tymi, którymi kierowały się badane matki. Dobierane były arbitralnie w oparciu o przesłanki teoretyczne i oceny sędziów kompetentnych. Mogą więc znacznie różnić się od tego, w jaki sposób badane matki uzasadniały swoją akceptację mitów. W dalszych badaniach warto byłoby sprawdzić rozumienie przez matki kluczowych pojęć, tj. dobro dziecka, jego szczęście, przyjaźń z nim, i ich opinie na temat powodów, dla których dany mit wychowawczy jest przez nie akceptowany. Ponadto niewykluczone, iż wybrane przez nas mity wychowawcze są przez znaczną część matek przyjmowane bezrefleksyjnie. Jest możliwe, że w nawale rodzicielskich obowiązków matki kierują się w dużym stopniu oszczędnością poznawczą (Fiske, Taylor, 1991): stosują uproszczenia myślowe, które pomagają im zrozumieć złożony przekaz kulturowy, popularyzujący określone mity wychowawcze. W rezultacie nie zastanawiają się głębiej nad ich podstawami, nie racjonalizują swoich przekonań i nie uzasadniają wynikających z nich zachowań.

Mamy także świadomość innych ograniczeń. Po pierwsze, ze względu na stosunkowo małą liczebność próby, wyniki prezentowanych badań nie mogą być generalizowane na szerszą grupę rodziców. Obraz badanych zmiennych może charakteryzować wyłącznie dobraną przez nas próbę matek. Po drugie, pomiar badanych zmiennych oparty był na deklaracjach matek, na które wpływ mogły mieć zarówno ich chęć zaprezentowania się w lepszym świetle (np. w dążeniu do aprobaty społecznej), jak i nastawienie wobec badania; zmiennych tych nie kontrolowano. Nie wiemy na przykład, czy uczestniczki badań wskazywały określone przekonania/zachowania jako społecznie oczekiwane, czy też jako korzystne dla rozwoju ich dziecka. Z teoretycznego punktu widzenia są to zupełnie różne perspektywy oceny. W koń$\mathrm{cu}$, pewien wpływ na osiągnięte wyniki mogła mieć stosunkowo duża rozpiętość w wieku badanych matek (od 22 do 50 lat). Problem wieku rodziców w wychowaniu dziecka jest rzadko podejmowany we współczesnej literaturze przedmiotu, a jeśli już, to w węższym kontekście, np. nastoletniego macierzyństwa czy rozwoju dzieci uzdolnionych (zob. np. Bidzan, 2013; Janicka, Liberska, 2014). Nie jest wykluczone, że ze względu na coraz późniejszy wiek rodzenia pierwszego dziecka przez kobiety w społeczeństwach rozwijających się, nie tyle wiek życia badanych matek, ile raczej wiek życia, w którym urodziły one pierwsze dziecko, może być źródłem odmiennych doświadczeń i wzorów rodzicielstwa zakłócających obraz relacji między badanymi przez nas zmiennymi.

Uogólniając, możemy powiedzieć, że osiągnięte wyniki potwierdzają znaczną popularność wśród badanych matek przekonań odpowiadających wyróżnionym mitom wychowawczym o „nadrzędnej wartości dziecka”, konieczności „zapewnienia mu szczęścia” i ,zaprzyjaźnienia się z nim", zarówno w deklarowanych przez nie przekonaniach, jak i w deklarowanych zachowaniach wobec własnych dzieci. Jednakże przyjęty przez nas model teoretyczny relacji między tymi przekonaniami i zachowaniami a sądami badanych matek o stereotypowych powodach postępowania współczesnych rodziców, zgodnych z tymi mitami, uzyskał jedynie częściowe potwierdzenie. O ile o deklarowanych zachowaniach matek możemy $\mathrm{z}$ dużym prawdopodobieństwem wnioskować na podstawie ich 
przekonań o „nadrzędnej wartości dziecka”, potrzebie ,zapewnienia mu szczęścia” i ,zaprzyjaźnienia się", o tyle stereotypowe powody takiego postępowania mają ograniczone zastosowanie w przewidywaniu przekonań i zachowania badanych matek wobec własnych dzieci. Wynikałoby z tego, że postępowanie matek wobec dzieci nie jest prostą funkcją ulegania wpływom społecznej ,mody" na sposób wychowania uznawany za ,idealne rodzicielstwo”.
Mimo wskazanych wyżej ograniczeń zdecydowaliśmy się opublikować osiagnięte w tym badaniu rezultaty z dwóch powodów. Dotyczą bowiem nowej problematyki, związanej z obserwowaną we współczesnych społeczeństwach zmianą stosunku rodziców do dziecka jako jednej z nadrzędnych wartości. Ponadto uznaliśmy, że osiagnięte w tym badaniu rezultaty można potraktować jako podstawę dalszych w tym zakresie badań.

\section{PRZYPISY}

${ }^{1}$ M. Zychal zrealizowała część zadań związanych z konstrukcją narzędzia KOMMD oraz gromadzeniem i kodowaniem danych.

${ }^{2}$ Analizy obejmujące wyniki KSWR dotyczą podgrupy 78 matek. Średnie wyników KOMMD tej podgrupy nie różniły się w sposób istotny statystycznie od wyników pozostałej części próby.

\section{BIBLIOGRAFIA}

Ajzen I., Fishbein M. (1980), Understanding attitudes and predicting social behavior. Englewood Cliffs, NJ: Prentice Hall.

Arnett J. (2004), Emerging adulthood. A winding road from the late teens through the twenties. New York: Oxford University Press.

Aronson E., Wilson T.W., Akert R.M. (1997). Psychologia Spoleczna. Serce i umyst. Poznań: Wydawnictwo Zysk i S-ka.

Bakiera L. (2013), Zaangażowane rodzicielstwo a autokreacyjny aspekt rozwoju dorostych. Warszawa: Wydawnictwo Difin.

Baumrind D. (1972), Socialization and instrumental competence in young children. W: W.W. Hartup (red.), The young child: Reviews of research. Vol. 2 (202-224). Washington, DC: National Association for the Education of Young Children.

Bidzan M. (2013), Nastoletnie rodzicielstwo. Perspektywa psychologiczna. Gdańsk: Harmonia.

Bieńko M. (2015), Perfekcyjna matka oraz bachor w poradnikach i bezradnikach współczesnej popkultury. W: I. Taranowicz, S. Grotowska (red.), Rodzina wobec wyzwań wspótczesności: wybrane zagadnienia (91-106). Wrocław: Oficyna Wydawnicza Arboretum.

Bowlby J. (1951), Maternal care and mental health. Geneva: World Health Organisation.

Cherlin A.J. (2010), The marriage go-round: the stage of marriage and the family in america today. New York: Vintage Books.

Chiu L.H. (2007), Child-rearing attitudes of chinese, chinese-american, and anglo-american mothers. International Journal of Psychology, 22, 4, 409-419.

Davidson A.R., Jaccard J.J. (1979), Variables that moderate the attitude-behavior relation: Results of a longitudinal survey. Journal of Personality and Social Psychology, 37, 8, 1364-1376.

Długosz P. (20913), Sytuacja absolwentów studiów wyższych na rynku pracy a jakość wykształcenia. Nierówności Społeczne a Wzrost Gospodarczy, 33, 43-54.

Fishbein M., Ajzen I. (1975), Belief, attitude, intention, and behavior: An introduction to theory and research. Reading, MA: Addison-Wesley.

Fiske S.T., Taylor S.E. (1991), Social cognition. From brains to culture. Second Edition. New York: McGraw-Hill. 
Goh E. (2011), China's one-child policy and multiple caregiving: raising little suns in Xiamen. New York: Routledge.

Gordon T. (1991), Wychowanie bez porażek. Warszawa: Instytut Wydawniczy Pax.

Hays S. (1996), The Cultural contradictions of motherhood. London: Yale University Press.

Heszen I. (2014), Psychologia stresu. Warszawa: PWN.

Janicka I., Liberska H. (2014), Psychologia rodziny. Warszawa: PWN.

Kagitcibasi C. (1982), The changing value of children in Turkey. Current studies on the value of children. Number 60-E. Honolulu, HI: East West Population Institute Publication.

Kagitcibasi C., Ataca B. (2005), Value of children and family change: a three-decade portrait from Turkey. Applied Psychology: An International Review, 54, 3, 317-337.

Kopp C.B. (1982), Antecedents of self-regulation: a developmental perspective. Developmental Psychology, $18,199-214$.

Kościelska M. (2011), Odpowiedzialni rodzice. Z doświadczeń psychologa. Kraków: Oficyna Wydawnicza Impuls.

Liberska H. (2007), Współczesny obraz moratorium. W: B. Harwas- Napierała, H. Liberska (red.), Tożsamość a wspótczesność (25-52). Poznań: Wydawnictwo Naukowe UAM.

Maccoby E., Martin J. (1983), Socialization in the context of the family: Pattern-child interaction. W: E.M. Hetherington (ed.), Handbook of child psychology: Socialization, personality, and social development, 4, 1-102. New York: Wiley.

Miller C.L. (2014), Little emperors and an Army of Orphans: the government's control over the idea of family in an overpopulated world. University Honors Program Theses. Paper 1.

Nauck B. (2014), Value of children and the social production of welfare. Demographic Research, 30, 66, $1793-1824$.

Nawroczyński B. (1929), Swoboda i przymus w wychowaniu. Warszawa: Nasza Księgarnia.

Padilla-Walker L.M., Nelson L.J. (2012), Black hawk down? Establishing helicopter parentingas a distinct construct from other forms of parental control during emerging adulthood. Journal of Adolescence, 35, $1177-1190$.

Palęcka A., Szczodry H. (2010), Hipermacierzyństwo - na przykładzie matek osób z niepełnosprawnością intelektualną. W: A. Palęcka, H. Szczodry, M. Warat (red.), Kobiety w społeczeństwie polskim (17-42). Kraków: Wydawnictwo Uniwersytetu Jagiellońskiego.

Schiffrin H.H., Liss M., Miles-McLean H., Geary K.A., Erchull M.J., Tashner T. (2014), Helping or hovering? The effects of helicopter parenting on college students' well-being. Journal of Child \& Family Studies, $23,548-557$.

Sears W., Sears M. (2001), The attachment parenting book: a commonsense guide to understanding and nurturing your baby. Boston: Little, Brown and Company.

Selye H. (1978), Stres okielznany. Warszawa: Państwowy Instytut Wydawniczy.

Senior J. (2015), Dużo radości, mniej przyjemności. Paradoks współczesnego dzieciństwa. Poznań: Media Rodzina.

Sternberg R.J. (1986), A triangular theory of love. Psychological Review, 93, 2, 119-135.

Szymanik-Kostrzewska A. (2016), Dziecko jako projekt rodzicielski? Przekonania matek na temat wychowania i ich percepcja zachowań dziecka. Warszawa: Wydawnictwo Difin.

Śliwerski B. (2003), Pedagogika negatywna. W: Z. Kwieciński, B. Śliwerski (red.), Pedagogika. Podręcznik akademicki. Tom I (436-451). Warszawa: PWN.

Tokarski J. (red.) (1980), Stownik wyrazów obcych. Warszawa: PWN.

Trempała J. (2010), Obsesyjna miłość rodziców do dziecka. Przyczynek do dyskusji. Roczniki Naukowe WSIiE TWP w Olsztynie, 1-2, 169-180.

Trempała J., Czyżowska D. (2004), Rozwój moralny. W: B. Harwas-Napierała, J. Trempała (red.), Psychologia rozwoju człowieka. Tom 3. Rozwój funkcji psychicznych (106-130). Warszawa: PWN.

Umberson D., Gove W.R. (1989), Parenthood and psychological well-being: theory, measurement, and stage in the family life course. Journal of Family Issues, 10, 4, 440-462.

Schoenebeck H. von (2008), Wolność od wychowywania. Kraków: Oficyna Wydawnicza Impuls. 


\section{ANEKS}

\section{Skala WD: Wartości Dziecka}

WD1a. Rodzic, który nie stara się o wszystko, co najlepsze, dla swojego dziecka, nie jest dobrym rodzicem.

WD1b. Zawsze staram się dawać mojemu dziecku to, co najlepsze.

WD2a. Obowiązkiem rodzica jest zapewnienie dziecku jak najlepszych możliwości nauki, także poprzez wybór dobrego przedszkola i szkoły.

WD2b. Robię, co mogę, by zapewnić mojemu dziecku jak najlepszą edukację, a także szeroki dostęp do zabawek edukacyjnych, programów edukacyjnych, internetu i technologii.

WD3a. Potrzeby rodzica nie powinny być ważniejsze od potrzeb jego dziecka.

WD3b. W moim życiu dbam najpierw o potrzeby mojego dziecka, dopiero potem o swoje.

WD4a. Dobry rodzic zawsze znajduje czas dla dziecka, nawet także, gdy jest zmęczony albo chory.

WD4b. Jeśli moje dziecko czegoś ode mnie chce, nie liczy się dla mnie to, że jestem zmęczona lub źle się czuję.

WS4c. Swój wolny czas przeznaczam przede wszystkim dla dziecka.

WD5a. Rodzic powinien dbać o to, by rzeczy dla dziecka były jak najlepszej jakości.

WD5b. Staram się dawać mojemu dziecku wszystko to, co najlepsze, np. zabawki, ubrania, jedzenie.

WD6a. Dobry rodzic powinien zapewnić dziecku jak najwięcej różnych zabawek, książek czy filmów.

WD6b. Staram się, żeby moje dziecko miało wiele różnorodnych zabawek, książek, filmów.

WD7a. Rodzic powinien przede wszystkim zadbać, żeby dziecko mogło oddawać się swoim ulubionym zajęciom, dopiero potem myśleć o swoim hobby.

WD7b. Dbam, żeby moje dziecko mogło rozwijać swoje zainteresowania, mniej ważne jest rozwijanie przeze mnie moich zainteresowań.

WD8a. Wydatki na przyjemności dla dziecka powinny być ważniejsze od wydatków na przyjemności rodzica.

WD8b. Dodatkowe pieniądze wolę przeznaczyć na prezent dla mojego dziecka niż dla siebie.

\section{Skala SD: Szczęśliwe Dzieciństwo}

SDla. To na rodzicu spoczywa pełna odpowiedzialność za to, by dziecko miało szczęśliwe dzieciństwo.

SD1b. Bardzo się staram, by zapewnić mojemu dziecku szczęśliwe dzieciństwo.

SD2a. Dobry rodzic nigdy nie powinien przedkładać swojego szczęścia nad szczęście swojego dziecka.

SD2b. Dbam o szczęście mojego dziecka bardziej niż o swoje. 
SD3a. Rodzic nie powinien narzucać dziecku wielu obowiązków.

SD3b. Staram się nie obciążać mojego dziecka wieloma obowiązkami.

SD4a. Uważam za niewłaściwe zmuszanie dziecka do robienia czegoś, czego nie lubi (z wyjątkiem rzeczy absolutnie koniecznych, jak np. higiena).

SD4b. Nie zmuszam mojego dziecka do czynności, których nie chce robić, chyba że jest to coś koniecznego (np. mycie się).

SD5a. Obowiązkiem rodzica jest chronić dziecko przed porażkami i związanymi z nimi rozczarowaniem i smutkiem.

SD5b. Staram się chronić moje dziecko przed niepowodzeniami, przykrymi emocjami, jak np. smutek czy rozżalenie.

SD6a. Dobry rodzic nie powinien odmawiać dziecku tego, czego ono bardzo chce.

SD6b. Nigdy nie odmawiam mojemu dziecku tego, czego bardzo pragnie - chyba że jest to dla niego szkodliwe albo niebezpieczne (np. ostry nóż).

SD7a. Rodzic powinien postarać się, żeby dziecku nie brakowało tego, czego jemu zabrakło w dzieciństwie.

SD7b. Daję mojemu dziecku wszystko to, czego sama nie miałam w dzieciństwie, żeby nie odczuło braku.

SD8a. Rodzic nie powinien zmuszać dziecka do robienia czegoś, czego ono nie lubi, tylko je w tym zastąić.

SD8b. Jeśli moje dziecko nie chce czegoś zrobić, nie zmuszam go i zwykle je w tym wyręczam.

\section{Skala P: Przyjaźń z Dzieckiem}

PD1a. Uważam, że dobry rodzic powinien zaprzyjaźnić się ze swoim dzieckiem.

PD1b. Moje dziecko ma we mnie - jako w rodzicu - przyjaciela.

PD2a. Rodzic powinien szanować opinię dziecka na równo ze swoją.

PD2b. Opinia mojego dziecka jest dla mnie tak samo ważna jak moja i zawsze się z nią liczę.

PD3a. Uważam, że dobra relacja z dzieckiem wymaga traktowania dziecka na równi z rodzicem.

PD3b. Traktuję moje dziecko, jakby było mi równe - takie traktowanie sprawia, że nasze relacje są dobre.

PD4a. Uważam, że przyjacielskie stosunki pomiędzy rodzicem i dzieckiem są dla rozwoju dziecka lepsze niż relacja, w której dziecko podporządkowuje się rodzicowi jako opiekunowi.

PD4b. Staram się być przyjacielem dla swojego dziecka - nie opiekunem, któremu ma się podporządkować.

PD5a. Dobry rodzic nie powinien narzucać dziecku swojej woli, tylko zawsze dyskutować z nim i po przyjacielsku, wspólnie ustalać zasady.

PD5b. Nigdy nie narzucam mojemu dziecku mojego zdania, tylko rozmawiam z nim i wspólnie ustalamy zasady.

PD6a. Najlepiej jest, gdy relacja rodzica z dzieckiem opiera się na przyjaźni i współdziałaniu. PD6b. Opieram relację z moim dzieckiem na przyjacielskich stosunkach i współpracy. 